\title{
THE SPIRITUAL SIGNIFICANCE OF KOMBURONGO IN THE FOLK BELIEFS OF THE DUSUNIC PEOPLES OF NORTH BORNEO
}

\author{
Low Kok On \\ Borneo Heritage Research Unit \\ Universiti Malaysia Sabah, Malaysia \\ e-mail:lowkokon@ums.edu.my \\ Solehah Ishak \\ Faculty of Film, Theatre \& Animation \\ MARA University of Technology, Malaysia \\ e-mail: solehahishak@gmail.com
}

\begin{abstract}
Early Western ethnographers who conducted field research in North Borneo (Sabah, Malaysia) in the late nineteenth century were attracted to the komburongo (Acorus calamus or sweet flag) because of the spiritual role it played in the folk beliefs of the Dusunic speaking peoples. Although there have been brief discussions on the komburongo, in-depth studies are still lacking. This article is based on the data collected and conclusions made by interviewing informants as well as the material obtained from direct field observations. The primary aim is to focus on the various spiritual functions and roles played by the komburongo in the lives of the Dusunic peoples then and now. This study finds that the komburongo fulfils several important roles, both in their ritual ceremonies and spiritual healings. The komburongo is believed to be a form of a benevolent spirit which functions as the spiritual helper in various rituals. Its rhizomes are used as a ritual instrument, also called the komburongo, which serves as the medium connecting the ritual practitioner to the invisible spirits from the nether world. Komburongo leaves are also used as amulets to protect the users from evil spirits. These myriad beliefs in the komburongo have been rooted and embedded in the Dusuns' ancestral traditions and practices since time immemorial. Nevertheless, these beliefs have become less dominant ever since the Dusunic ethnic groups became Christians or Muslims.
\end{abstract}

Keywords: benevolent spirits, Dusunic peoples, evil spirits, folk beliefs, komburongo, ritual ceremonies, traditional and spiritual healings

Komburongo or komboungo ${ }^{1}$ (commonly known as sweet flag in English) is a precious plant for the Dusunic ${ }^{2}$ ethnic groups residing in Sabah, Malaysia. Evans 
(1953: 60) reported in his study that the komburongo was in fact a cultivated and not a native plant found growing wildly in North Borneo (former name for Sabah, Malaysia). During our field research in several districts in Sabah from 2013 to 2015, we found that many Dusun villagers in places like Pitas, Membakut, Kuala Penyu, and Ranau (Fig. 1) still planted the komburongo around the swamplands near their houses.

In his book, The Religion of the Tempasuk Dusuns of North Borneo (1953), Evans described the komburongo's role in the Dusuns' traditional religious ceremonies. His brief account formed an important source about the spiritual role of the komburongo in the lives of the Dusuns in the 1940s. In Sabah, the rhizomes of the komburongo plant have also been used by some members of Kadazan and Dusun ethnic groups as traditional medicine to cure stomach aches and fevers (Tongkul 2002: 32). ${ }^{3}$

In their belief system, the komburongo is a type of spiritual helper who has the power to aid the bobolian ${ }^{4}$ (ritual specialist) to resolve spiritual problems or disturbances that occur in people's daily lives. Dusun ritual specialists, known variously as bobolian, bobohizan, tantagas or bobolizan, depending on the different Kadazan and Dusun subgroups, are almost always women, although there

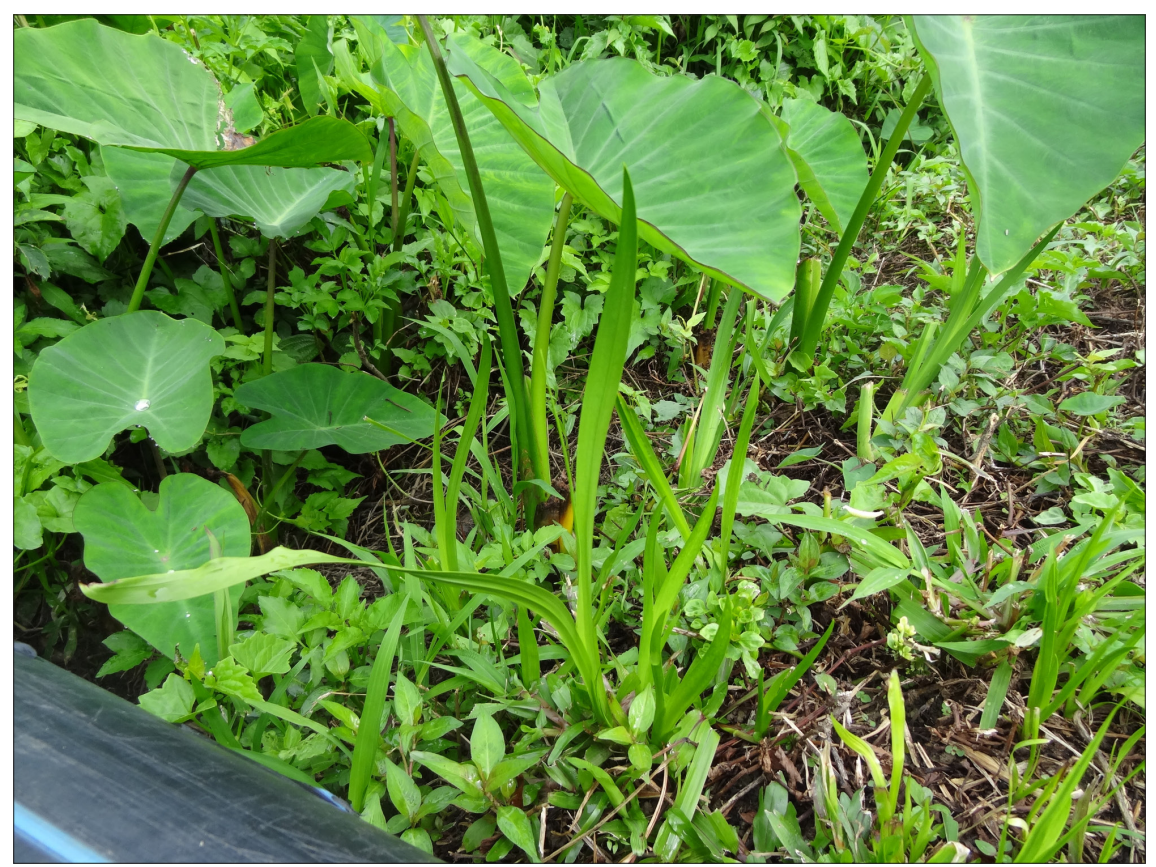

Figure 1. Komburongo (next to the keladi-Colocasia esculenta) planted by the villagers around their houses in the District of Ranau. Photograph by Low Kok On 2014. 
are also male ritual specialists. The roles of male and female ritual specialists differ (Low \& Marshall 2013: 20). As reported by Evans (1953: 42), and based on our own research, nearly all the major Dusun religious rites are performed by the female priestesses, known as bobolians. Among the Kimaragang Dusun, for example, both women and men can be bobolians although the spiritual powers and knowledge of the rinait (ritual poem) of the former are better and stronger than those of the latter (Low \& Pugh-Kitingan 2015: 407). Women bobolians perform complex ritual ceremonies related to paddy-planting, healing, and the banishment of evil spirits. Rituals performed not by female but by male bobolians include performing rites when opening a new piece of land for rice-planting or pacifying the spirits when cases of incest have occurred. Male bobolians would also assist in other smaller unspecified ceremonies (Low \& Pugh-Kitingan 2015: 407).

The spiritual roles of Acorus calamus are also found rooted in many cultures both in the West and in the East. One of the earliest records of the sweet flag is the calamus in the Bible. It was first mentioned when God told Moses to make holy oil to anoint the tabernacle, the ark of testimony, and other ritual paraphernalia (Exodus 30:23, 24, 34). Calamus was also one of the plants said to have grown in the gardens of Solomon (Solomon 4:14) (quoted by Hashmat et al. 2013: 289). Among the North American indigenous peoples, the calamus served as a powerful shamanic libation, a panacea, health tonic and detoxifier, and a talisman against evil. Indeed, this plant is saturated with spiritual magic and universal connectivity (Ratsch 1998: 41). Many cultures throughout the world believe that rhizomes of the sweet flag contain potent powers that ward off evil. According to Morgan (1980), countless North American tribes hung calamus rhizomes in their homes and sewed it into children's clothing; the belief was that the plant would ward off nightmares and cause evil to pass by homes and families. In ancient China, the calamus was evidently used in shamanism, and is one of the country's oldest, most revered plants. Bundles of calamus rhizomes tied together with Artemisia vulgaris (mugwort) are still hung over doorways to protect against evil spirits, and used as talismans during the dragon boat festival (Motley 1994). All this serves to highlight the various important functions universally played by the Acorus calamus.

Amongst the Dusunic peoples, although Acorus calamus known as the komburongo continues to play an important role in traditional and spiritual functions, specific research has yet to be conducted. Evans' (1953) early ethnographic research mentioned the spiritual functions of the komburongo in the lives of the Dusun ethnic people of Tempasuk in the District of Kota Belud; Hurlbut (1986) was interested in komburongo's role as a divato, the assistant spirit, helping the Kadazan ethnic ritual expert in Labuk, eastern Sabah. Tongkul (2002) only 
referred to the rhizomes of the komburongo, which were used to cure sicknesses like stomach aches and fevers, without delving into the spiritual functions associated with this plant. Hanafi (2003) only mentioned the role of the komburongo as a ritual instrument of the Kadazan ethnic group in Penampang. His study focuses on the roles of the bobolian (ritual specialist) of that area. All the above proves that, until our current research and fieldwork, a specific study on the spiritual aspects of the komburongo was very much lacking.

Field research to gather information regarding the spiritual significance of the komburongo was conducted from October 2013 until August 2015 in the districts of Kota Marudu, Ranau, Tuaran, Kota Belud, Kudat, and Kuala Penyu, where a majority of the people are from the Dusunic group. This research hopes to fill in the gaps of the earlier studies carried out by Evans (1953), Hurlbut (1986), Tongkul (2002), and Hanafi (2003). Data gathered from these Dusunic informants are closely tied to beliefs in spiritual beings and the use of the komburongo in spiritual healings. This ethnographic research on the komburongo, in all its myriad functions and roles, is done within the trajectory of the worldview of these Dusunic peoples.

\section{KOMBURONGO AND THE WORLDVIEWS OF THE DUSUNIC PEOPLES}

According to Hanafi (2003: 28), the Kadazan ethnic group in the Penampang District of Sabah believed that the komburongo came into being because the Kinoringan, their Creator, wanted to make sure that their ritual specialists would always succeed in conducting their ritual ceremonies. Based on this orally transmitted myth, the komburongo is believed to be sacred and has invisible powers to help ensure that mankind would not be threatened by evil spirits, the rogon.

This has a close affinity with the Dusunic ethnic people who believed that the etheric self of the empirical world of human beings would be the invisible, spiritual world of the good and bad spirits. Evans (1953), Williams (1965), Hurlbut (1986), Porodong (2001), Mat Zin (2003), Phelan (2005), Hanafi (2007), and other researchers have reported that the Dusunic group comprised of the Rungus, Kimaragang, Dusun, Kadazan, and many others, all believed in the existence of evil and good spirits of the nether realm. ${ }^{5}$

According to Mat Zin (2003: 23), before the natives of Sabah embraced Christianity and Islam, belief in supernatural beings as well as in good and evil spirits had played a very important role in all aspects of their lives. In the belief system of the Dusunic peoples, there existed a number of spirit categories: among the 
Kadazan in the Labuk area (east of Sabah), spirits are classified as: rogon (malevolent spirits that harm people), divato (helping spirits), tombiruvo (souls of the dead), bambarayon (rice spirits), and binorit (race of small people) (Hurlbut 1986: 114). Hurlbut (ibid.: 125) reported that the divatos (helping spirits) are called by ritual specialists to help heal sickness. There are many divatos, and the komburongo is the strongest among them. The Kadazan believe that when a person is sick, his or her soul has been captured by a malevolent spirit. If the divato is successful in getting back the sick person's soul, the person will recover.

Beliefs in spirits and ritual taboos have greatly influenced the lives of the Dusunic people (Evans 1978 [1922]: 152). Evans' (ibid.) statement was further supported by Williams' (1965: 17) findings that personal crises associated with births, sicknesses, deaths, fortunes, misfortunes, hunting, and crop yields were marked by the Dusuns as occasions where it was necessary to deal with these forces by engaging in specific ritual behaviours.

Thus it is crucial to have a harmonious balance between the real world of human beings and the nether world of the spiritual beings, which must never be jeopardized. The Dusunic people believed that improper behaviours like committing incest would disrupt this harmonious balance and incur the wrath of the spiritual beings besides having misfortune befalling on the individual, his or her family members, and even the whole community. This harmonious balancing and co-existence between the spiritual and physical worlds are closely related to the concepts of ahasu (hot) and osogit (cold). To disrupt this balance would cause a heated (ahasu) situation, yielding even more problems as more people would fall ill or they would have a bad harvest (Lasimbang 2002: 2; Hanafi 2008: 176; Pugh-Kitingan \& Baptist 2009: 251).

To prevent this, the Dusunic people undertook various rituals so that both the physical and spiritual realms would continue to co-exist harmoniously. Should a situation become ahasu (bad), steps must be undertaken to cool it down, namely to make it osogit so that it could become good again. Only a bobolian who possesses the knowledge to connect these two different physical-spiritual, seen-unseen dimensions would be able to do this. The bobolian would be aided by the divato. This research analyses the forms and spiritual functions of the komburongo in its role as the divato (helper) of the bobolian, and is concerned with these ancestral beliefs seen within the context of the worldview of the Dusunic groups until the present day. This is best exemplified by a recent newspaper report (dated 5 June 2015) about an earthquake in Sabah. It was believed that the mountain spirits among the indigenous Kadazan and Dusun were unhappy and became angry. To show their anger, they caused the earthquake to happen. But even before the real happening, the Daily Express (2015: 2) reported that a highly respected bobohizan from Penampang, Sabah, had 
predicted that something bad would happen because of the behaviour of the ten tourists who decided to strip naked at the summit of Mount Kinabalu, which the indigenous peoples of Sabah, especially the Dusunic peoples, deemed to be sacred. As reported in the newspaper, the bobohizan stressed that the actions of the ten tourists had awakened and offended the komburongo spirit (the subject of this study) of Kinabalu. "The Mountain is getting 'hot' and to cool it down, sacrifices must be made. It would take a huge sogit (ritual fine), in fact, a bloody sacrifice to appease the angry spirit," said the bobohizan (ibid.). This incident exemplifies how the Dusunic indigenous people express their concerns and disapprovals of untoward and unbecoming behaviours from outsiders who seem oblivious of their traditional values. Making public their predictions, by using the newspaper media, serves to prove the need to state their innate, traditional values and beliefs whilst publicly chastising unbecoming modern behaviours.

On 21 June 2015, it was again reported on the main page of the same newspaper that traditional Dusun ritual specialists, the bobolians, had conducted the biggest ever animal sacrifice to appease the spirits of Mount Kinabalu. The report stated:

The ritual began at $8.30 \mathrm{am}$. It saw Pangkau (the ritual specialist) lead six other bobolians to the location where they were going to conduct the monogit ritual. In the monogit ritual, they requested permission from the spirits that dwell in the area to conduct the mogondi (communicating with the guardians of the mountain). It took only a few minutes of chanting before one of the bobolians started to go into trance. At around $10.00 \mathrm{am}$, Pangkau, carrying a white chicken and her machete, approached the stone [which was] about a few metres away from where she had been sitting. After reciting her rinait (ritual poem), the chicken was slaughtered and its blood sprinkled onto the sacred stone. She then began communicating with the guardians of the mountain.

The ritual ended with the offerings of what looked like several types of leaves and the slaughtered chicken, which was left there for the spirits of the mountain to enjoy. Thereafter, seven buffaloes which the guardians had earlier demanded were sacrificed in quick succession, both as an appeasement and to ultimately strengthen the weakened mountain. (Patrick \& George Dol 2015: 1)

These two recent newspaper reports proved that the Dusunic peoples of Sabah continue to believe in the importance of maintaining a harmonious balance between the physical and spiritual realms, and that the komburongo still plays a very important role in their lives. 


\section{KOMBURONGO'S MYRIAD FUNCTIONS}

According to our Dusunic informants, there were two types of komburongo plants based on the colour of their rhizomes: the green and the red komburongo. The Dusunic people regarded the green komburongo to be female and the red to be male. Some believed that the power of the red komburongo, which was also more difficult to find, was stronger than that of the green komburongo. In our fieldwork conducted in the districts of Pitas, Kota Marudu, Ranau, and Membakut Kecil, we only found the green komburongo (Fig. 2).

The komburongo plant is used both in traditional medicine for its medicinal properties and in the spiritual healing of the Dusunic ethnic group. The komburongo's functions are varied for it has many roles: (1) as a type of a spiritual helper because it is believed to have the power and expertise to help the bobolian solve spiritual problems; (2) it is the scared object/instrument which the bobolian

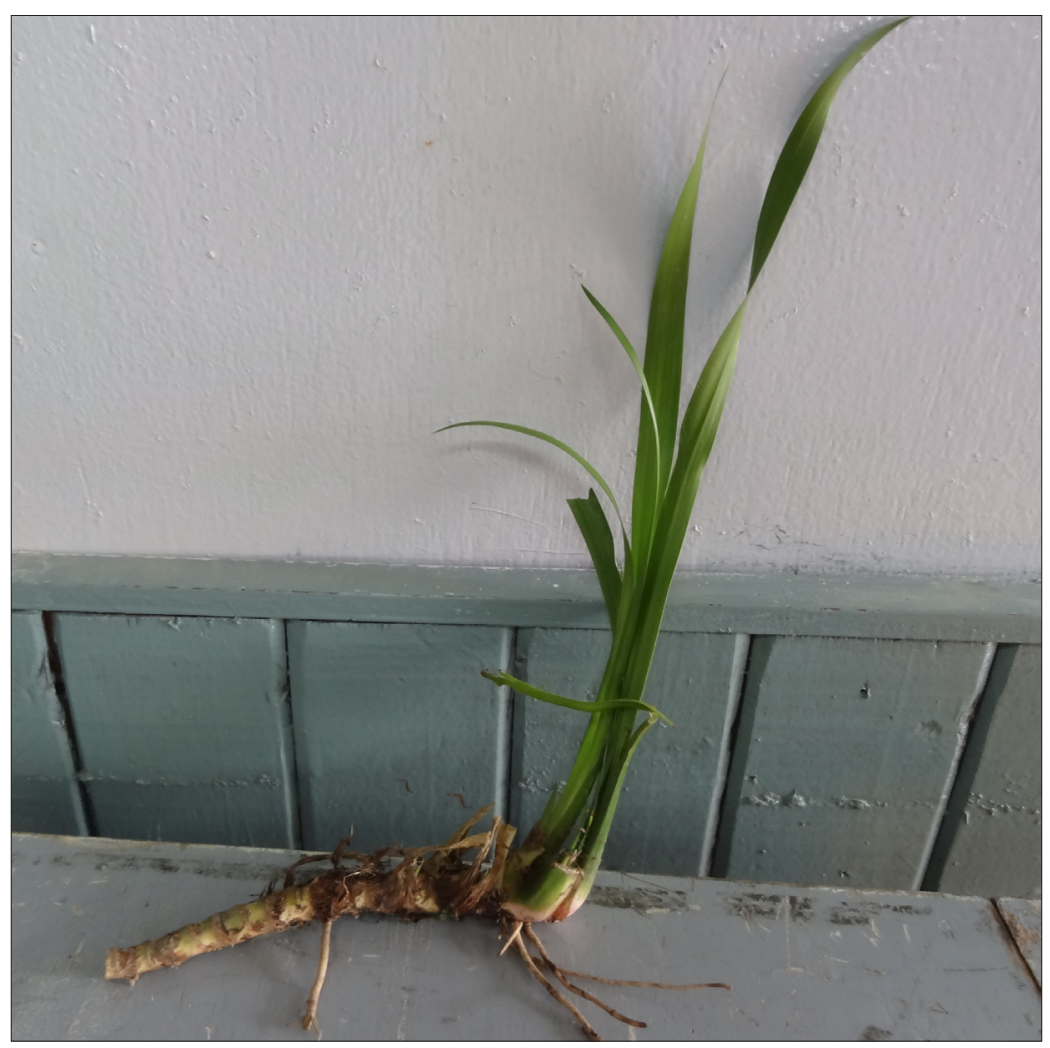

Figure 2. Green komburongo found in the District of Ranau. Photograph by Low Kok On 2014. 
uses as she conducts her ritual healings; (3) it is a familiar plant used by the Dusunic ethnic groups in their spiritual healings; (4) it functions as a spiritual consultant for the Dusunic group who would ask about their health issues or seek advice about their daily lives; (5) the leaves and roots of the komburongo (Fig. 2) are used to heal stomach aches, skin problems, and headaches. This research paper focuses only on the spiritual functions of the komburongo.

\section{KOMBURONGO AS SPIRITUAL HELPER}

The Dusunic ethnic group accepted the conception that the komburongo was created by Kinoringan (Creator) to help the bobolian to successfully communicate with the spiritual beings during ritual ceremonies. This would enable the bobolians to identify and solve the problems affecting members of their community. We also found that komburongo refers to three different things: komburongo the plant, komburongo the helping spirit, and komburongo as the ritual instrument. Our Dusun informant from the District of Tuaran told us that before the komburongo could be planted, rinaits, which are ritual verses, must be recited by the bobolian entrusted with the task. Failure to do so would not activate the spiritual powers of the komburongo, which on its own, either as the plant or the spirit or the ritual helper, would actually be quite useless, would have no powers, and would remain inactive without the recitations of the sacred rinaits. It is the sacred rinaits, memorised and recited by the bobolians, which have the power to evoke and activate the spiritual powers of the komburongo and hence empower it to fulfil its task either as the spiritual helper or the invisible spirits, both malevolent and benevolent.

Found in the swampy areas of Sabah, the komburongo is a cultivated marsh plant which does not have any spiritual qualities or connections to other worldly dimensions. It is only after the komburongo has been dried and tied with a variety of dried and "magical" elements, over which the bobolian has ceremonially recited various rinaits, that the komburongo would acquire its spirit and special qualities.

Unfortunately, our informants could not provide us with the rinaits used to empower the komburongo with its spiritual powers. This is understandable because throughout our research, we found a distinct behavioural pattern: informants would just be confessing what they had heard or knew previously or that they simply believed and accepted what they were told. Former bobolians could not recite the rinaits because the recitation had to be done only under certain conditions, almost always only when they were performing the actual ritual ceremony. These rinaits cannot just be simply recited for certain rituals 
must be adhered to. More importantly, for the rinaits or the komborungo or the bobolian to be effective, all three must work together, in tandem with one another. The bobolian without the komburongo would be ineffective without the recitation of the rinaits. Reciting the rinaits alone without the bobolian or the komburongo would be equally ineffective. For the ritual to be successful, all three must function, support and empower one another.

Different informants told us different things about the spiritual powers of the komburongo leaves: under certain conditions, it was believed that the komburongo leaves actually did have spiritual powers, or that there were those who believed that they should always carry the komburongo leaves with them before going into the jungle, as the leaves would protect them from all sorts of danger. Yet others believed that planting the komburongo plant near their houses would prevent evil spirits from approaching their homes to disturb the inhabitants. This practice is still upheld until today, with some of our informants bringing along the komburongo leaves, in spite of their change in religion and modern practices. Yet others were just telling stories of what was once a normal practice and belief.

During our fieldwork, we also found that the komburongo plants were commonly cultivated by the Dusunic ethnic groups who lived in the districts of Ranau and Membakut Kecil. These people believed that the komburongo if planted around their houses would be capable of protecting the inhabitants from being disturbed or haunted by evil spirits. They believed that the komburongo plant would act as a fence preventing the onslaught of attacks by evil spiritual beings.

Talking to different informants made us realize that basically there were two opposing views vis-a-vis the komburongo: firstly, that it was just an ordinary plant which became empowered with spiritual powers only after the recitation of rinaits, after which it was transformed into a potent agent in curing rituals; secondly, the komburongo was actually a sacred plant, embedded with strong spiritual powers, which just needed to be tapped and released. In both cases, it was clear that the Dusunic people were influenced by the fact that the komburongo was a type of spiritual helper or assistant. It did not really matter whether the komburongo got its powers after the recitations of the sacred rinaits, or the power was already embedded within its natural plant form. Whatever the case, the final result was still the same: it was a plant with supernatural, spiritual powers, crucial in the performance of the bobolian rituals.

Testimonies of the significance of the komburongo as a spiritual helper were seen in many rituals conducted by the bobolian of the Dusunic ethnic group. Our interviews with the Dusun, Kadazan, Kimaragang, Rungus, and Tobilung ethnic groups revealed that in most of the rituals performed by the bobolian 
for healing or harvesting, festivities, or for the purposes of protecting the environment and warding off evil spirits, the first thing they had to do was to invite the spirit of the komburongo. The central force of these rituals was the recitation of the rinait by the bobolian to first awaken and then to invite the komburongo and other spirits in the nether world to participate in the rituals.

Evans in his study (1953: 68) documented a rinait which he termed as "the invocation of the Komburongo spirits". This invocation of inviting the komburongo spirits to help the ritual specialist preceded the central rites at many ceremonies of the Dusunic people. One of such rinaits was furnished by Kunsuwoi, one of the most skilled bobolians in the Kadamaian village where Evans carried out his fieldwork in the 1940s. According to Kunsuwoi (quoted by Evans 1953: 68), all rites were originally learnt from Sagatapon (the name of a fish). The rinait goes:

\begin{tabular}{ll}
\hline Rinait & Translation \\
\hline Supik ku Komburongo & I with the Komburongo spirits, \\
Buruk ku rinokian & I scatter rice for the males. \\
Supik kandaiyong himboh & Standing together one above the other \\
Simbulditonduruhlasukanak-anakkoh & Leaping away after my children came \\
Anak-anak rumikot & My children arrived \\
Kajajai kotikid kointob & Each receiving by reckoning \\
Kotunong kolohau kapompon & Coming together when called \\
Momboh-homboh kasungkad kohunan & Going here and there, and together \\
& planting a staff, charm[ed] with soot \\
Pandai boros podolot & Clever at talking all sorts of things \\
Pononowali do walai & Occupying deserted houses \\
Pononolikud lambagan manganak & Putting behind them constantly - \\
& used paths of the children \\
Lambagan do rumibut & Then constantly-used paths of the wind \\
Olonsih tanak minorun & The smell of the earth moulded \\
Oinduk tolotud podsupuan apandai & Going upwards to see the rolling \\
& land of clever smiths' work \\
Aling bulawan nosumpong poiradan & Where damaged gold is remade \\
Koposion do tinan & A livelihood for the body
\end{tabular}

(Evans 1953: 64-65)

Shimomoto (1979) in his study on the myths of the Rungus ethnic group had also recorded and transcribed a rinait known as Pangalapik, which he obtained from a Rungus ethnic informant who lived in the District of Kudat. The Rungus ritual specialist, known as a bobolizan, would recite the rinait Pangalapik during the sacred ritual ceremonies; for instance, after the harvest seasons so as to send the rice spirits believed to live far away out at sea back to their 
original abodes. This could be seen from the first part of the rinait Pangalapik as transcribed by Shimomoto (1979: 78):

\begin{tabular}{ll}
\hline Rinait Pangalapik & Translation according to the context \\
\hline Posikai ku i Komburongo & I wake up the Komburongo \\
Rukahai ku i rinokizan & I wake up the male \\
Amu ku dara om posikan & If I don't wake him up \\
Tida ku dara om rukahan & If I have no intention to wake him up \\
Nokodop dati i sinundu & Maybe his power is in a sleeping stage \\
Nokoturu dati i linodu, & Maybe his wonders are in an inactive stage \\
Monimpaki Komburongo: & Komburongo (answers): \\
Mangampot ki rinokizan & Reacted as a male \\
Nunu ngaran ka i tiposik & Why did you wake me up? \\
... & ... \\
\hline
\end{tabular}

The first part of the rinait Pangalapik shows how the bobolizan responsible for sending home the rice spirits must first awaken the spirit of the komburongo. According to the Rungus ethnic informants, spirits from the invisible nether worlds were in a sleeping state and had to be awakened before they could participate in the sacred bobolian rituals. The above rinait proves that the komburongo served as the bobohizan's spirit helper to send the rice spirits to their original abode, far out at sea.

Former bobolians in the District of Ranau concurred that whatever rituals were performed, the following rinait was to be the first to be recited:

\begin{tabular}{ll}
\hline Rinait & Approximate translation \\
\hline Isu pikui Komburong & This is about the Komburongo \\
Hiburo kui rinokian & I mention about the male spirit \\
Isu pikui posiridot & And this is about the different spirits within it \\
& I mention the spirit so as to move \\
Hiburo kui palandako & Said with the tongue \\
Do posiri nondo dila & Uttered with the lips \\
Do palanda kodo munung & This is about Rinsui (spirit) \\
Isu pikui Rinsui & And this is about power \\
Hiburo kui bintayang & The Rinsui who wants to come \\
Do Rinsui do rumikot & The power that appears \\
Do bintayang do sumakoi & You will arrive at a house \\
Korikot koh nondowalai & You will enter a room in the house \\
Kosaboi koh nondo tongkoh & The house, the place where a ritual will begin \\
Do walai do susupian & The house with stilts where the ritual will \\
Do kongkod do dura anan & take place \\
\hline
\end{tabular}

(Informants Hasnah Yukin and Gangku Gombur, 30 June 2014) 
The recitation of the above rinait proves that the komburongo was the first helping spirit to be invited to participate in the ritual and that without the presence of the komburongo spirit, all rituals would become ineffective.

The Dusun ethnic group in the District of Tuaran shared the same belief of the komburongo, which was regarded as the much sought-after spirit to help them solve their myriad spiritual problems. A former Dusun ethnic bobolian in Tuaran stressed that the following rinait has to be recited before the commencement of the bobolian ritual:

\begin{tabular}{ll}
\hline Rinait Dusun Tuaran & Approximate translation \\
\hline Ongoi ko siti Komburongo. & Come here, oh you, Komburongo. \\
Mokitulung oku dot karamaian diti. & I seek your help in this ritual. \\
\hline
\end{tabular}

The process of invoking the komburongo spirit was repeated during our Kadazan ethnic Mamanta ${ }^{6}$ ritual fieldwork, conducted in the village of Limadang in the District of Membakut on 18 and 19 July 2014. In the opening Mamanta ritual called Manupih, three bobolians were seen carrying a bag filled with a piece of white cloth, yellow rice, and the komburongo leaves. Our informants told us that like other rituals, the bobolian had to invoke the spirit of the komburongo before calling on other spirits to participate in the ritual. The three bobolians used their fingers to twirl the komburongo leaves as they recited the rinaits (Fig. 3) in order to awaken the komburongo spirit and gather other surrounding spirits to participate in the Mamanta ritual.

Amongst the Dusun Ranau, Dusun Tuaran, Rungus, and Kadazan ethnic groups, the importance and effectiveness of the komburongo as a helping spirit has been generally acknowledged and accepted throughout generations.

\section{THE ROLE OF THE KOMBURONGO IN RITUAL CEREMONIES}

Dusun ethnic groups used the dried komburongo root as a ritual instrument, which they also called komburongo. Various rare objects believed to have invisible, spiritual powers were hung onto the dried komburongo rhizome. According to several informants, the bobolian, responsible for creating this ritual implement, would know which items were suitable to be hung and attached to the dried komburongo rhizome so as to enhance its power and effectiveness. The bobolian would then conduct the ceremony of reciting the sacred rinaits to enable the spirits to come and inhabit in the ritual instrument which would be used to aid those who have sought their help.

Figure 4 shows the komburongo decorated with animal teeth, sea shells, a wooden comb, a small glass bottle, a small bell, and other paraphernalia, all 


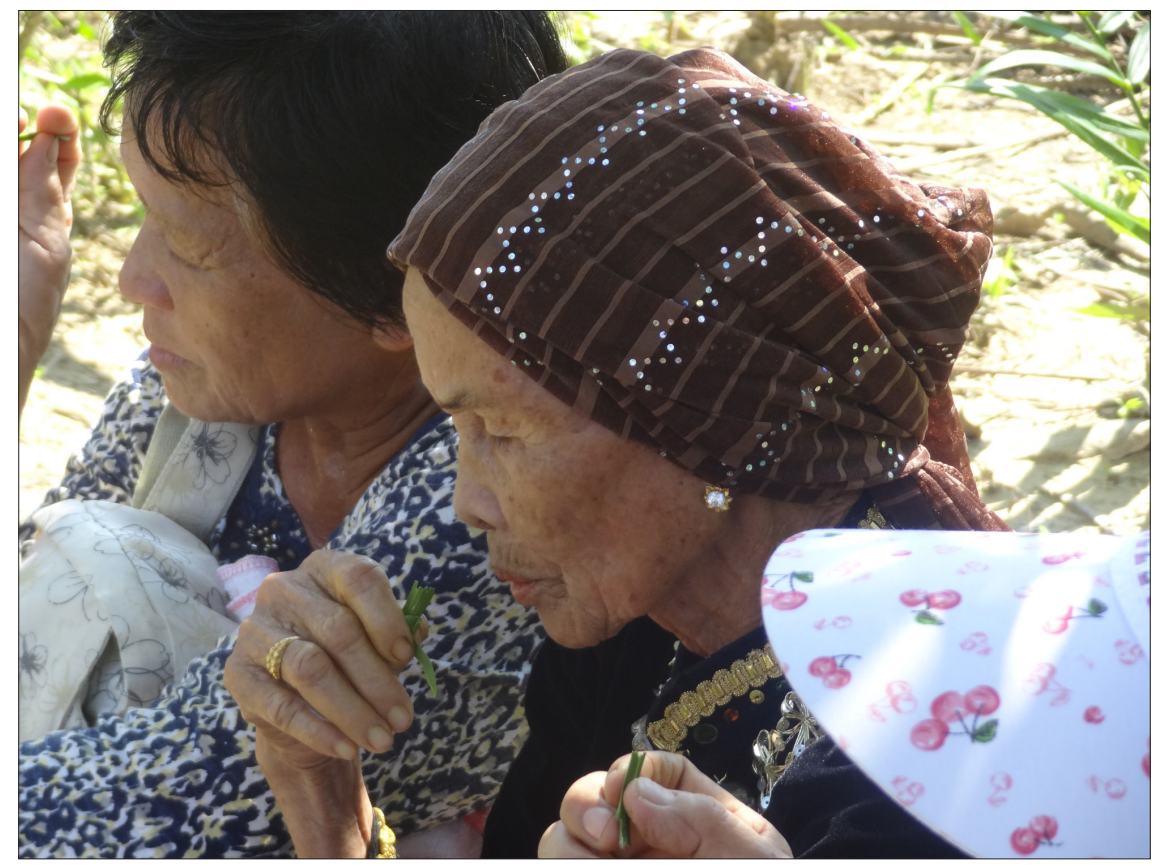

Figure 3. Three ritual specialists holding the komburongo leaves as they recite the rinait in a Mamanta ritual. Photograph by Low Kok On 2014.

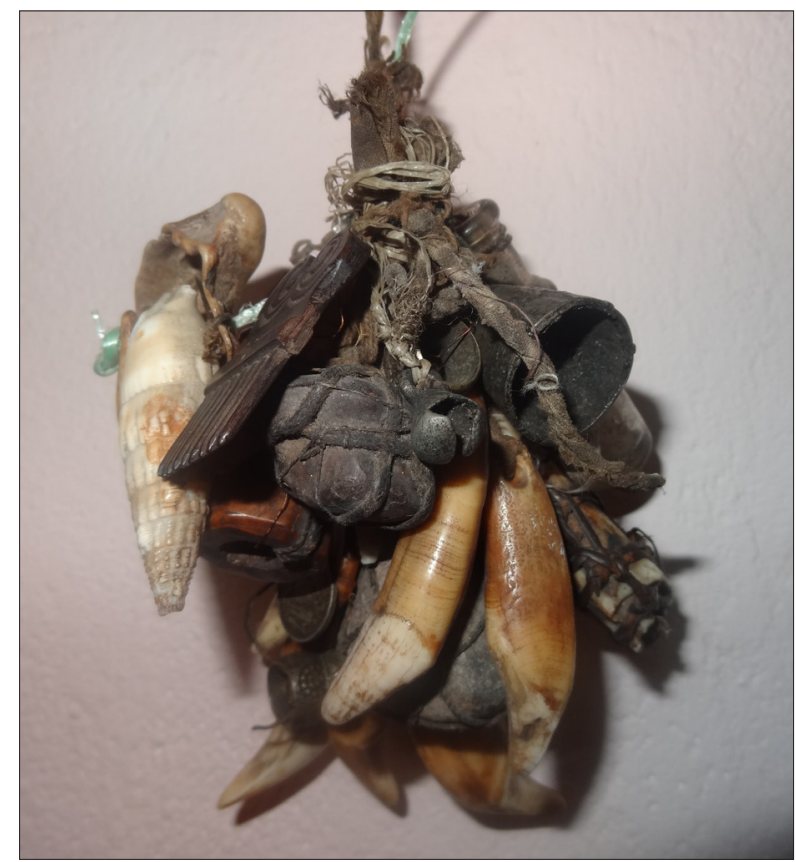

Figure 4. The komburongo ritual instrument decorated with what the ritual specialist considers to be magical items. Photograph by Low Kok On 2014. 


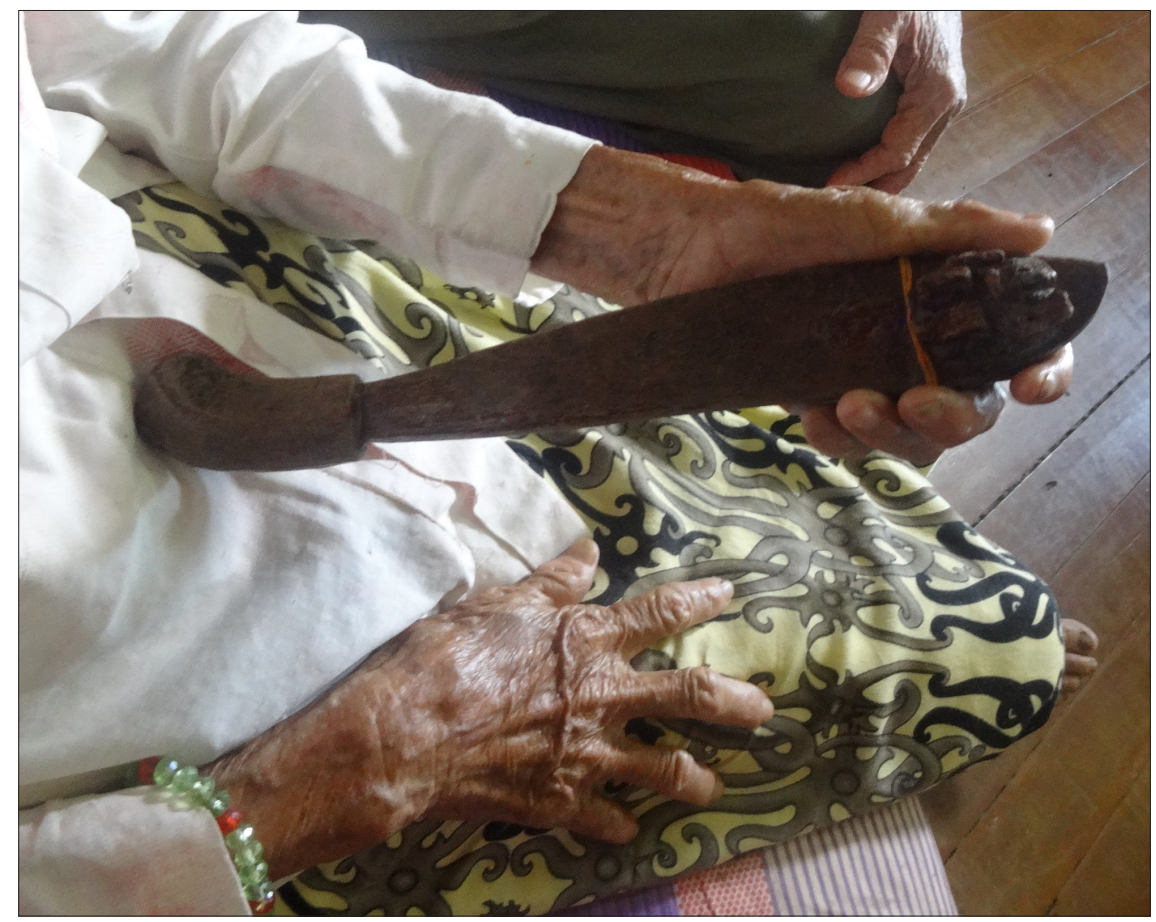

Figure 5. An informant showing an undecorated, knife-shaped komburongo. Photograph by Low Kok On 2014.

of which were believed to enhance the komburongo's spiritual powers. Other informants believed that only the komburongo had spiritual powers, but the other paraphernalia were merely decorative items. A komburongo ritual instrument without decorative items was found in the District of Membakut Kecil (see Fig. 5). ${ }^{7}$ With or without decorations, the komburongo as a ritual instrument has to undergo the process of having the bobolians recite the sacred rinaits. Without this ritual, the spirits would not come to empower the komburongo.

All the informants in this research (see the appendix) admitted that prior to converting to Christianity or Islam in the late nineteenth century, they depended on the help of the komburongo for many spiritual-related matters in their daily lives. They would consult the bobolian who had the help of the komburongo spirit to find out about health-related issues: when they got sick or were disturbed by evil spirits, or when they wanted to undertake a long journey and travel to faraway places or when they wanted to open new areas for planting rice. In these matters, the bobolian would consult the komburongo spirit to find cures, get advice or solutions to their numerous problems. 


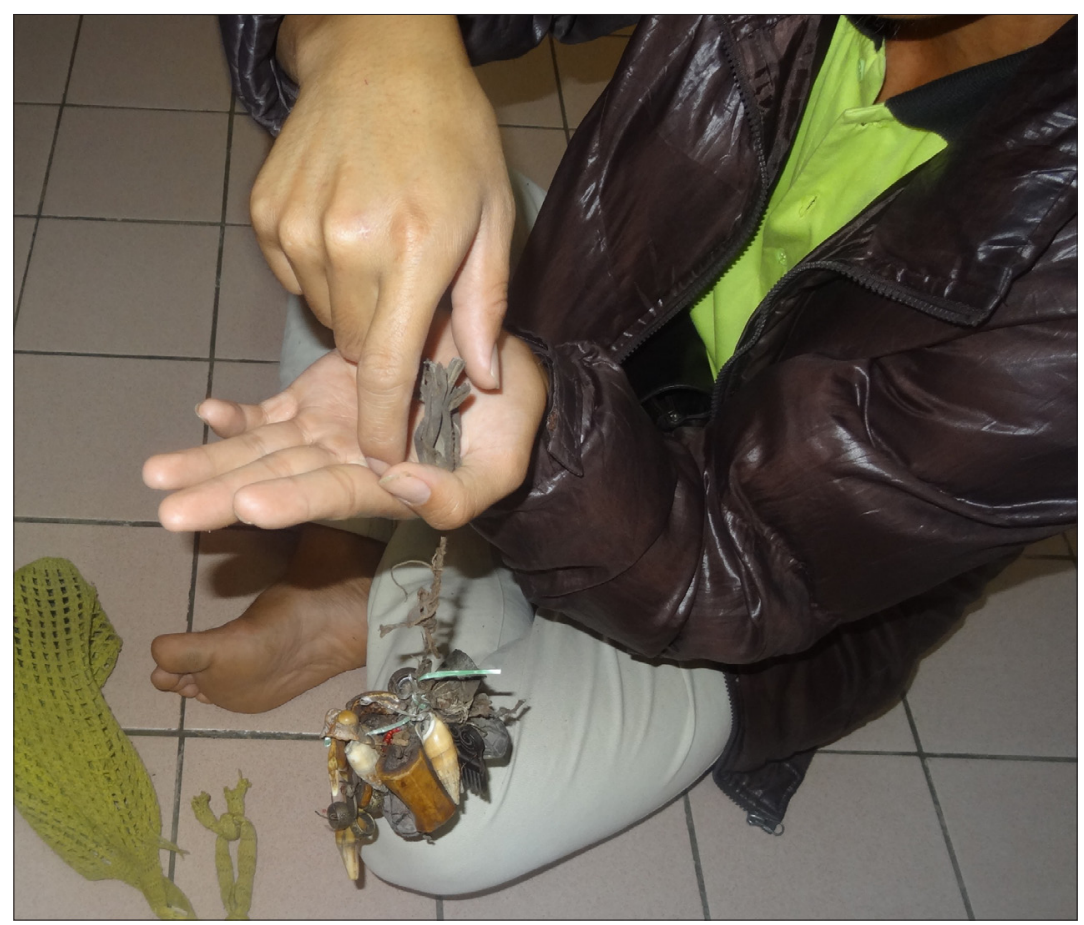

Figure 6. A Dusun informant in Ranau showing how the komburongo responded to the bobolian's questions, as seen from the movements of her index finger.

Photograph by Low Kok On 2014.

According to a Dusun informant from Ranau, who had watched the negotiating process with the komburongo, the bobolian would place her index finger on her palm and would ask questions related to the causes of the sickness. As soon as a question had been asked, if the bobolian's index finger moved in a straight manner, it meant that the answer was yes. But if the bobolian's index finger got entangled halfway, or it moved to one side, the answer was no or meant that whatever it was, it could not be done or helped. The negotiating process with the komburongo was dependent on the bobolian's expertise and the way she would be asking the questions related to the sickness, the possible cures, and other health-related issues (Fig. 6).

The following discussion was based on the observations of a komburongo healing ritual conducted by Tialum binti Siwoi (practitioner and informant), which she had learnt from another bobolian many years ago. This fieldwork was done in Kampung Limadang, Membakut, on 18 July 2014. The bobolian used a wooden knife-shaped komburongo ritual instrument (Fig. 7). Tialum revealed 


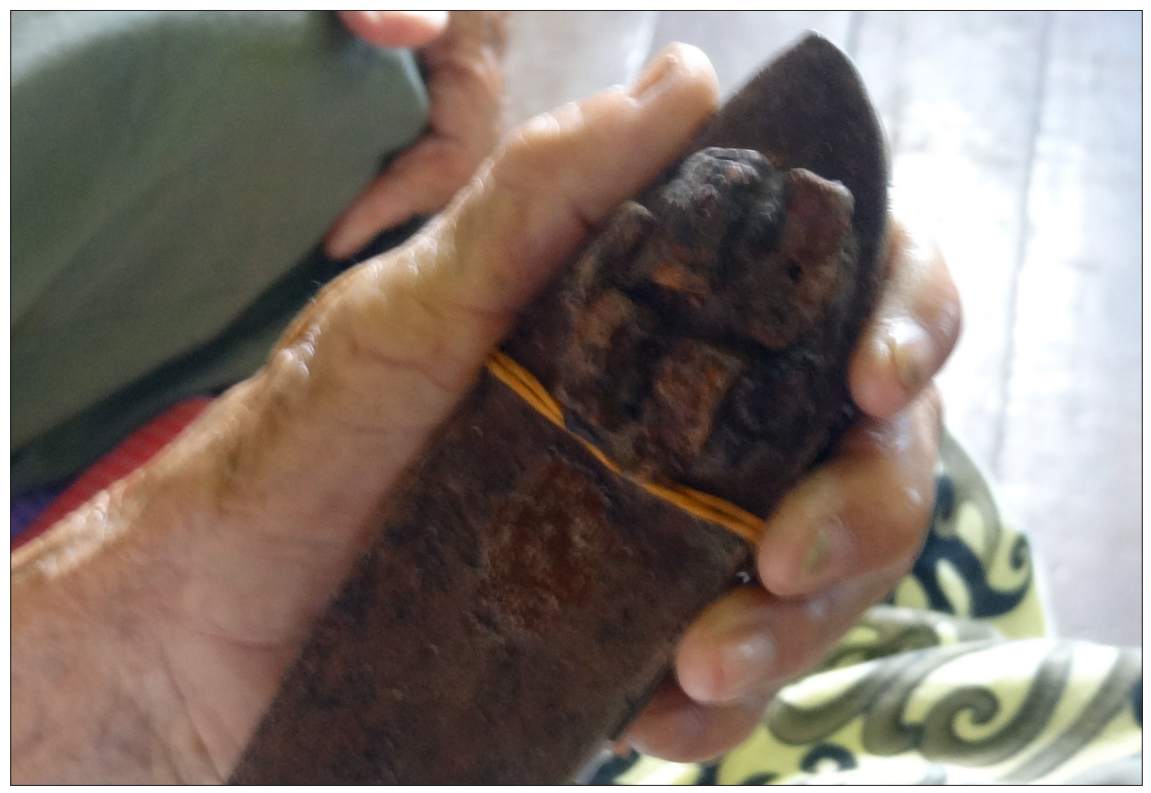

Figure 7. The dried komburongo placed at the end of a piece of wood. Photograph by Low Kok On 2014.

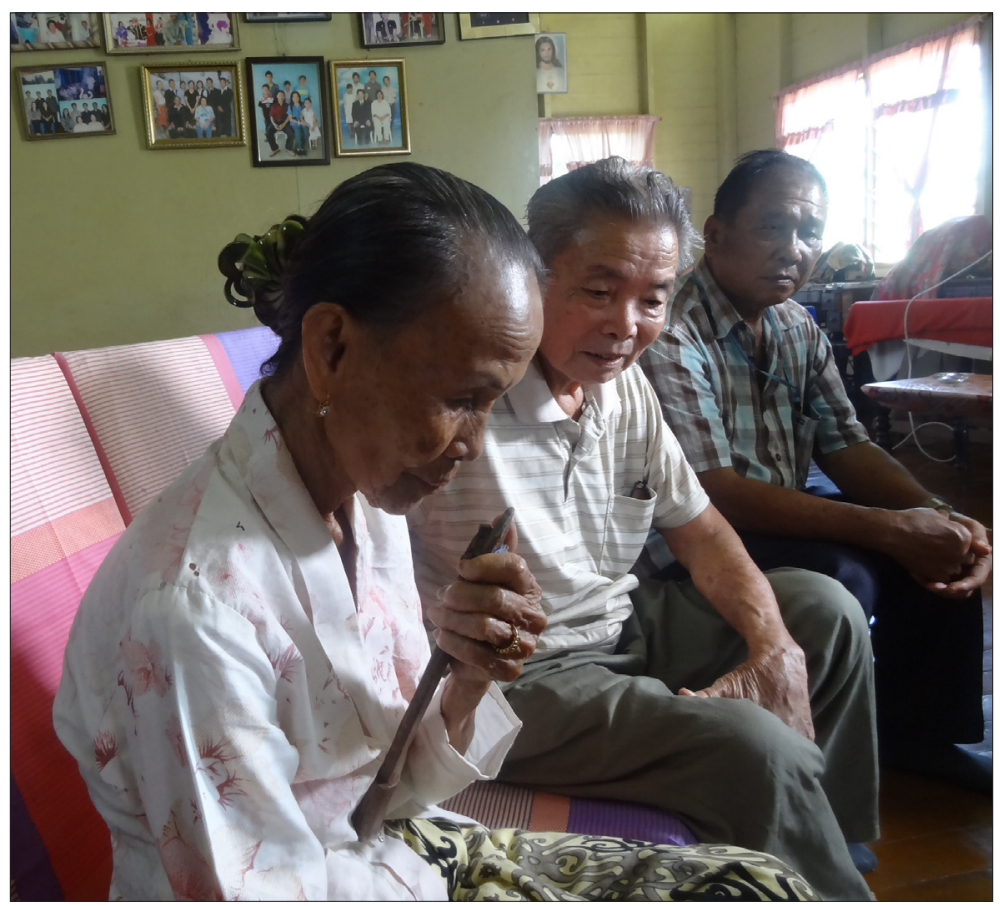

Figure 8. The bobolian places the komburongo near her mouth as she recites some ritual words. Photograph by Low Kok On 2014. 
that there was no hidden symbolic meaning to the knife-shaped piece of wood. It was merely a receptacle for her to place her fingers at the edge of the wooden piece, during the questioning session with the komburongo, which had been sanctified with the bobolian reciting the rinait. Those who wanted to ask the komburongo regarding their health, sickness or other spiritual problems had to hang RM1 ${ }^{8}$ at the end of the komburongo as a token payment for the bobolian.

Tialum had to be told the name of the sick person and the type of sickness, be it physical or spiritual. After getting the information, Tialum recited some verses (Fig. 8), and then immediately placed her finger on the wooden board. A question and answer session with the komburongo followed so as to determine how to solve the problems. This was indicated through the movements of the index finger which was initially placed close to the thumb, but as the session progressed, it would slowly move closer towards the komburongo (Fig. 9). If her finger moved right up to the edge of the wood, the answer was yes. If the finger was unable to completely move upwards to the edge of the wood, the answer was negative.

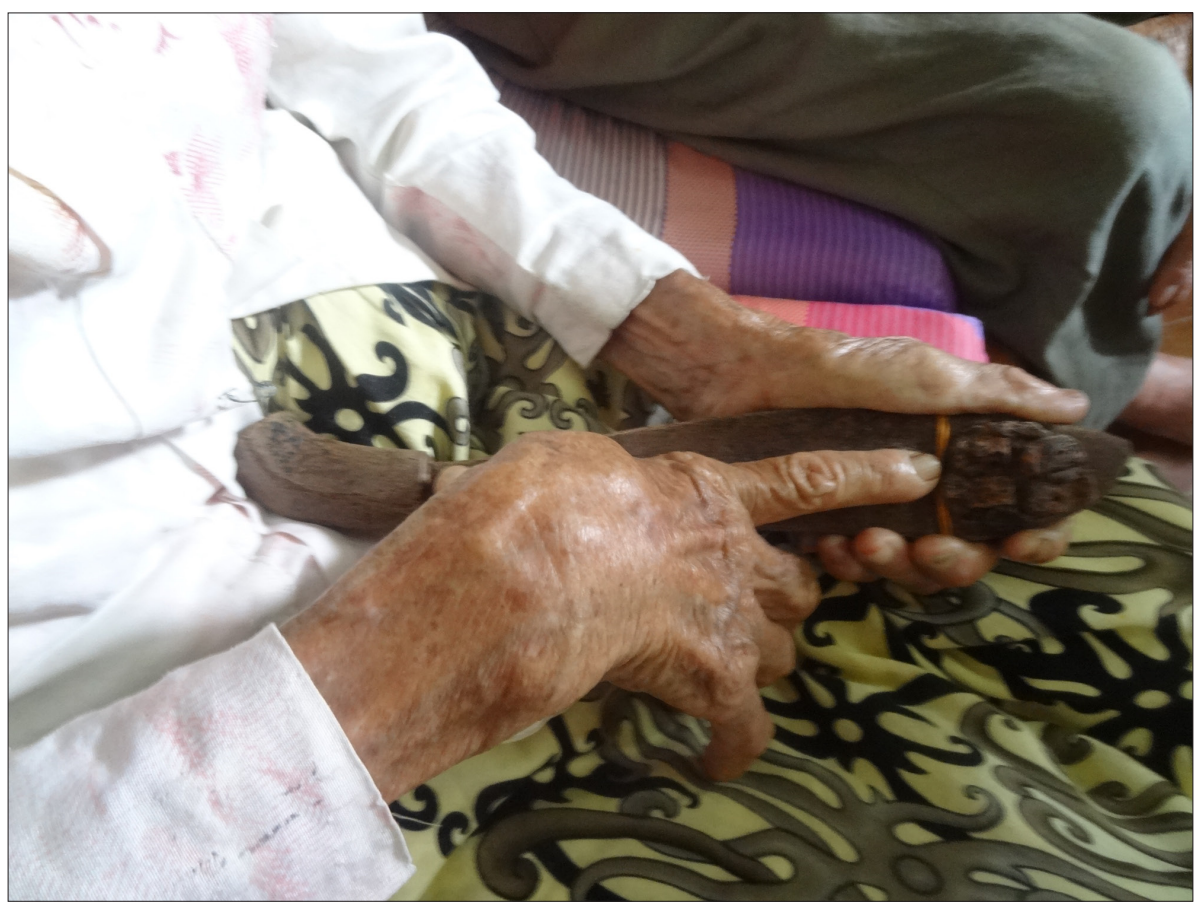

Figure 9. The bobolian's finger moving to the edge of the wood means that the answer is positive. Photograph by Low Kok On 2014. 
This ritual was a simplified version as the bobolian did not recite any rinaits or conduct any long rituals over the komburongo. After a few sessions of questioning and answering from the participants and Tialum, we concluded that it was important that the komburongo practitioner, like Tialum herself, be an experienced person well versed in various physical sicknesses. The bobolian's effectiveness was greatly dependent on her ability to communicate and get the answers from her helping spirit, the komburongo, whose responses, in turn, depended on how the former worded the questions. We also concluded that it was a very interdependent symbiotic relationship for a wrongly worded question to result in an inaccurate response and a wrong or ineffective cure.

\section{KOMBURONGO AS PROTECTOR}

In the belief system of the Kimaragang ethnic group in the northern part of Sabah, when someone was disturbed by the barau, an evil spirit, the most effective way of safeguarding the person was by burning the leaves of the dried komburongo. Smoke from the burning komburongo leaves would scare away the barau. The Kimaragang ethnic group believed that the barau could metamorphose into an animal or bird, as testified by several of our Kimaragang informants. If someone were to confront a barau in the shape of an owl, the apparition would emit a frightening sound. The weak-hearted might even faint. Should this happen, the barau would further attack and cause harm to the person. It was because of this that the Kimaragang ethnic hunters and jungle gatherers would always have matches and dried komburongo leaves with them whenever they entered the jungle.

The belief that the barau was afraid of the dried komburongo was related to the ancient belief of the Kimaragang ethnic people. According to an informant, Mojudin Gambus, a Kimaragang hunter, went to hunt in the jungle. As he was lying in wait to hunt the animals, he suddenly heard people conversing from afar. The hunter walked towards where he heard the conversation and when he came near to the place, he hid behind the trees and thick foliage. It was then that he discovered that the place was overgrown with komburongo plants and that a group of baraus were discussing about the komburongo from afar. An old barau was telling his friends not to go near the komburongo plant because it was forbidden by their ancestors. Likewise smoke from the dried komburongo leaves would endanger them. When all the baraus had left, the hunter approached the area that had an abundance of the komburongo plant. He quickly uprooted a komburongo plant to take home so that he could plant it near his house. When he arrived in his village, he told everybody about the 
conversation he had heard amongst the group of barau spirits. From then on the villagers knew how to combat threats and dangers coming from the baraus. It would also prevent them from getting lost in the jungle.

Hurlbut (1986: 129) reported that when a Kadazan died in the Labuk area, the komburongo was used as an amulet to prevent a living person's soul from following the soul of the deceased. The amulet, made from a piece of cloth, had a dried komburongo root wrapped inside; it was then tied around the wrist of the person. The data collected during our field research proved that many other Dusunic peoples also used the komburongo as an amulet.

The Kimaragang ethnic group also believed that when children were crying non-stop, most probably they were disturbed by the evil spirit, the barau. The Kimaragang believed that children, but not the adults, could see the presence of the barau. To resolve this problem, a small piece of root from the komburongo plant was cut and then wrapped in a piece of cloth. It would then be tied to the child's wrist as an amulet. Several Dusunic informants from other areas also believed in this practice and they, too, used this method to stop children from crying incessantly.

The Kadazan ethnic group residing in the District of Membakut cut the dried komburongo root into small pieces, pierced them, and then strung together to form a necklace. They too believed that this komburongo necklace would prevent evil spirits from disturbing children. Their children would wear these necklaces as a preventive measure to safeguard them against the evil spirits.

Several Dusunic ethnic informants told us that the komburongo plants were planted around their homes to prevent evil spirits from coming and disturbing them. During our fieldwork in the village of Lamadang in Membakut, we found that several Kadazan ethnic villagers planted the komburongo at the back of their houses (Fig. 10) as a safety precaution. More importantly, they would always have easy access to the komburongo, whenever they needed it.

Other Kadazans from Membakut said that the komburongo leaves could be folded into small circles or crumpled into small balls (Fig. 11) and mixed with cold or warm bath water to be used when bathing. The same informant told us that bathing in the water with komburongo leaves in it would dispel winds from the body. This was further corroborated by a Dusun informant from Ranau, who said that bathing in the water with komburongo leaves in it would cure itchy skin problems, make the person healthy, and generally ensure the wellbeing of the person, including preventing the onslaught of spiritual problems.

Yet other informants told us that when they were very young, komburongo leaves were placed underneath their pillows to prevent evil spirits from coming to disturb them when they were asleep, as it was then that they were most susceptible to attacks and disturbances. Some Dusunic ethnic groups believed 


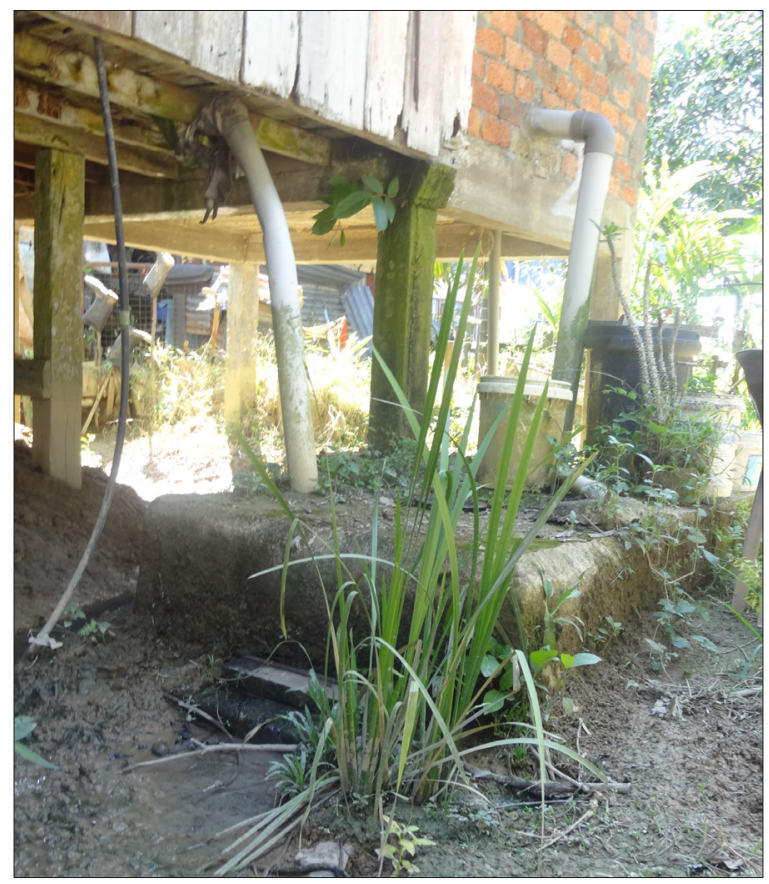

Figure 10. Komburongo at the back of a Kadazan ethnic house in the District of Membakut. Photograph by Low Kok On 2014.

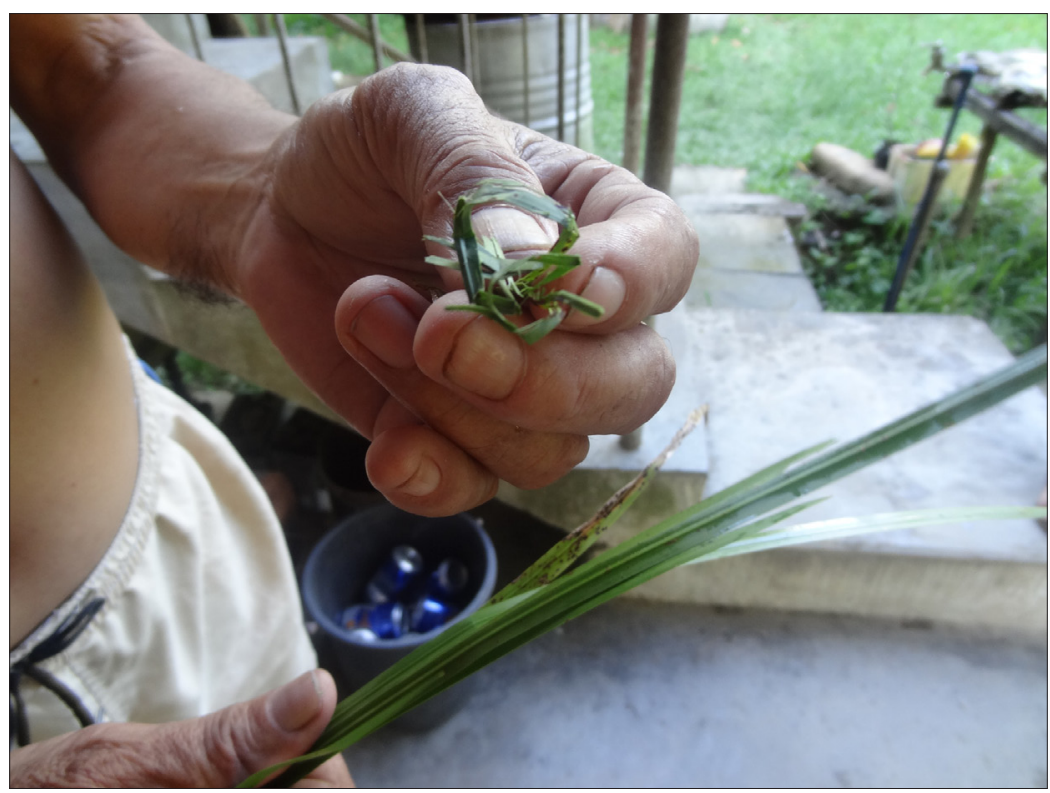

Figure 11. An informant showing how to fold the komburongo leaves before putting them in the bathwater. Photograph by Low Kok On 2014. 
that before they attended any festivities or large gatherings, they always had to carry with them komburongo leaves or an amulet in their shirt or trouser pocket, so as to prevent people who were envious of them from doing them harm. They would also carry the komburongo leaves when they had to travel in the middle of the night, so as to prevent attacks from evil spirits.

During our second fieldwork session we were told that Dusunic ethnic primary and secondary school children would take the komburongo leaves with them when they went camping, for they believed that evil spirits would not disturb them in their camping grounds, a terrain which was unfamiliar to them.

\section{THE SPIRITUAL FUNCTIONS OF THE KOMBURONGO: THEN AND NOW}

When Evans undertook his ethnographic study in North Borneo in the late 1940s and early 1950s, he found that the komburongo was greatly used in the religious affairs of the people. In fact, for ceremonial and religious purposes the rhizomes of the komburongo cannot be simply and casually gathered in just any ordinary way, or at any ordinary time. The rhizomes could only be taken during a religious ceremony of the first rank, involving the sacrifice of a pig (Evans 1953: 61). When this research was conducted in 2014, we found that our Dusun informants, in various villages, used these plants for various purposes and not only in ritual ceremonies. Dried komburongo rhizomes were made into bracelets to serve as amulets to protect them from being harmed and disturbed by evil spirits. When a baby cries non-stop at night, the komburongo is used to ward off the invisible spiritual beings disturbing the child. Young Dusunic students also believe in the efficacy of these leaves. As such they take the komburongo leaves with them to their camping sites so that they will not be harmed and disturbed by the evil spirits. It is obvious that even now belief in the spiritual qualities of the komburongo remains intact among some of the Dusuns although its primary importance and main function in religious ceremonies as earlier reported by Evans (1953) have changed.

Evans' (ibid.: 61-62) report of his fieldwork detailed the complicated process of collecting the komburongo plants from their growing sites to be used in various ritual ceremonies among the Dusuns of the Kadamaian area of North Borneo:

I was lucky enough to see komburongo dug during a very complicated Magambawon ceremony at Bengkahak village, about four or five miles from Kadamaian. Subsequently, I saw a party of women at Piasau (another nearby village) on their way to take komburongo, while a Magambawo ceremony was in progress at that village. 
At Bengkakak, there were three women, accompanied by a man carrying a sword and a round wooden shield went to the marshy streamlet where the komburongo grew. The man made some passes with his sword, before the women started grubbing up the rhizomes. This was done to drive away those unwanted spirits.

When the party with the komburongo was approaching the house on its return journey, a sortie was made by some of its male inhabitants, all armed with weapons, and a very brief sham fight took place, with the woman's defender participated. The fight developed into a sort of war dance, after which the attacking party escorted the komburongo to the house, where it was placed on the altar, before being shared among the women who required it. The 'fight' is supposed to energize the rhizomes.

Such a complicated ritual process is no longer practised these days. During our field trip we observed how the Kadazan people living in Membakut simply dug up the komburongos which were planted near their houses. They did so directly and simply without any ritual or complicated process whatsoever. This happened in 2014 during the Mamanta ceremony held to please the various spirits along the river by making offerings to them.

In her research among the Dusun, Koepping (2006: 69) noted that there were Christians who retained a deep awareness of and respect for the traditional belief system but felt following it was wrong after they had converted to Christianity or Islam. Low and Pugh-Kitingan (2015: 418) report that many Kimaragang Dusun informants in the Pitas District said that bobolians had become extinct in their villages due to theses conversions and modernizations which resulted in their not practicing these agriculture-related ritual ceremonies. Besides the Kimaragang Dusun, the numbers of bobolians for other Dusun subgroups in Sabah are also gradually declining. Our study of the komburongo in 2014 saw many changes, especially when the majority of our Dusun informants had converted to either Christianity or Islam, leaving behind their animistic and pagan beliefs.

At the time of our field research (2013-2015), about $80 \%$ of the Dusunic ethnic group had become Christians and another $10 \%$ had reverted to Islam. Nevertheless, it has to be stressed that conversion to Christianity or Islam has not totally eradicated the traditional Dusuns' worldview, for belief in spirits still impacts their lives which continue to be sustained by tradition, ceremonies, and offerings.

The current situation seems to be a whirlpool of interdependent factors affecting the practitioner, practice, and the "believer". The gradual demise of the bobolians has consequently led to the gradual reduction of ritual ceremo- 
nies, which in turn has also impacted the roles and functions played by the komburongo.

The dialectics of modernity, tradition, religion, and ritual practices will continue to be openly played amongst practitioners who still believe in their ritual practices but must circumvent religious beliefs, and amongst those who feel that they must cease to engage in these rituals completely. There are also those in the community who believe that whilst their religion forbids them to engage in these ritual or spiritual practices, they are somehow duty-bound to preserve these rituals as manifestations of their culture and tradition. Under these circumstances, even as the bobolians' very existence seems to be precarious, the komburongo will continue to exist in its various manifestations, albeit in different permutations.

\section{CONCLUSION}

On the whole, this paper has highlighted that the komburongo played a very important spiritual role in the lives of the Dusunic ethnic people either as the helping spirit, ritual instrument or an amulet. The spiritual functions of the komburongo were closely linked to their ancestral beliefs and worldviews. These beliefs were stronger before the Dusunic people embraced Christianity or Islam, for they believed that the komburongo as a helping spirit was created by the Kinoringan (their Creator) to help them whenever they were in difficulty and were encountering problems. As a ritual instrument, the komburongo was used in paddy-planting activities, festivals, and spiritual healings. Komburongo rhizomes and leaves were often used as amulets by different Dusunic ethnic groups to safeguard them from dangers which they believed came from evil spirits.

When the majority of our Dusun informants have converted to either Christianity or Islam, leaving behind their traditional beliefs, changes in the spiritual functions of the komburongo are found inevitable. Nevertheless, it has to be stressed that these animistic beliefs are still practised. Conversion to Christianity or Islam has not totally eradicated the traditional Dusuns' worldview, for believing in spirits continues to impact their lives sustained by tradition, ceremonies, and offerings. Changes in their religion have not resulted in a radical shift, nor have they altered their worldviews.

The dialectics of modernity, tradition, religion, and ritual practices will continue to be openly played amongst practitioners who still believe in their ritual practices but must circumvent religious beliefs, and amongst those who feel that they must cease to engage in these rituals completely. There are also 
those amongst the community who believe that whilst their religion forbids them to engage in these ritual/spiritual practices, they are somehow duty-bound to preserve these rituals as manifestations of their culture and tradition. Under these circumstances the komburongo will continue to exist in its various manifestations even as the bobolians' very existence continues to be precarious.

\section{APPENDIX}

\section{List of Informants}

Note: The following informants were interviewed between October 2013 and August 2015. Several Rungus and Dusun informants did not want their names to be revealed, thus only their initials are used (see 6-10). All informants who were interviewed belonged to the Dusunic ethnic group except for Jasman Bandar. He is a Bajau, but since early years he had been brought up amongst the Kimaragang ethnic group in the District of Kota Marudu.

\begin{tabular}{|r|l|l|l|l|l|l|}
\hline No. & Informant & Age & Ethnicity & Gender & Place & Occupation \\
\hline 1. & $\begin{array}{l}\text { Mojudin bin } \\
\text { Gambus }\end{array}$ & 60 & Kimaragang & Male & $\begin{array}{l}\text { Kota } \\
\text { Marudu }\end{array}$ & Farmer \\
\hline 3aul bin & 52 & Kimaragang & Male & $\begin{array}{l}\text { Kota } \\
\text { Marudu }\end{array}$ & Native chief \\
\hline 4. & $\begin{array}{l}\text { Gangku binti } \\
\text { Gombor }\end{array}$ & 74 & Dusun & Female & $\begin{array}{l}\text { Ranau } \\
\text { Mata }\end{array}$ & $\begin{array}{l}\text { Farmer } \\
\text { former } \\
\text { bobolian }\end{array}$ \\
\hline 5. & $\begin{array}{l}\text { Hasnah binti } \\
\text { Yukin }\end{array}$ & 62 & Dusun & Female & Ranau & $\begin{array}{l}\text { Housewife / } \\
\text { former } \\
\text { bobolian }\end{array}$ \\
\hline 6. & MBK & 43 & Dusun & Female & Ranau & Maid \\
\hline 7. & BBK & 62 & Dusun & Female & Ranau & $\begin{array}{l}\text { Former } \\
\text { teacher }\end{array}$ \\
\hline 8. & BBA & 43 & Dusun & Male & Ranau & Technician \\
\hline 9. & ITM & 56 & Dusun & Female & Ranau & Teacher \\
\hline 10. & SK & 86 & Dusun & Male & Ranau & Village head \\
\hline
\end{tabular}




\begin{tabular}{|r|l|l|l|l|l|l|}
\hline 11. & $\begin{array}{l}\text { Munchi binti } \\
\text { Dapit }\end{array}$ & 81 & Dusun & Female & Tuaran & $\begin{array}{l}\text { Farmer / } \\
\text { former } \\
\text { bobolian }\end{array}$ \\
\hline 12. & $\begin{array}{l}\text { Tialum binti } \\
\text { Siwoi }\end{array}$ & 80 & Kadazan & Female & Membakut & $\begin{array}{l}\text { Komboungo } \\
\text { practitioner / } \\
\text { spiritual } \\
\text { consultant }\end{array}$ \\
\hline 13. & $\begin{array}{l}\text { Abraham bin } \\
\text { Henry }\end{array}$ & 36 & Kadazan & Male & Membakut & Teacher \\
\hline 14. & $\begin{array}{l}\text { Adong binti } \\
\text { Otim }\end{array}$ & 69 & Kadazan & Female & Membakut & Trader \\
\hline 15. & Olat bin Aluan & 90 & Kadazan & Male & Membakut & Farmer \\
\hline 16. & $\begin{array}{l}\text { Perim bin } \\
\text { Junah }\end{array}$ & 62 & Kadazan & Male & Membakut & Farmer \\
\hline 17. & $\begin{array}{l}\text { Picony Pitin } \\
\text { 18. }\end{array}$ & 36 & Kadazan & Female & Membakut & Housewife \\
\hline 18. & $\begin{array}{l}\text { Ungut binti } \\
\text { Tawi }\end{array}$ & 61 & Kadazan & Wanita & Membakut & Housewife \\
\hline 19. & $\begin{array}{l}\text { Raymond bin } \\
\text { Majumah }\end{array}$ & 40 & Rungus & Male & Kudat & Teacher \\
\hline 20. & $\begin{array}{l}\text { Jasman bin } \\
\text { Bandar }\end{array}$ & 26 & Bajau & Male & $\begin{array}{l}\text { Kota } \\
\text { Marudu }\end{array}$ & Student \\
\hline
\end{tabular}

\section{NOTES}

1 Komburongo is the term used by the Dusun, Kimaragang, and Rungus ethnic groups, whereas the Kadazans in Membakut refer to it as the komboungo.

2 This term refers to the ethnic communities in Sabah, Malaysia, who speak the Dusunic languages. The 1970 Population Census of Sabah categorised them as Dusun, Costal Kadazan, Kimaragang, Eastern/Labuk Kadazan, Lotud, Kuijau, Tatana, Tanggara, Bisaya, Rungus, and Dumpas (Lasimbang 1996: 179). The Dusunic informants of this study are the Dusun, Kadazan, Kimaragang, and Rungus.

${ }^{3}$ Acorus calamus is popular not only amongst the Dusunic peoples but also among other races and ethnic groups in Malaysia who use them as medicinal plants. Muhamad and Mustafa (1994: 147) reported that traditionally, the Malays in Malaysia used Acorus calamus, locally known as jerangau, for treating rheumatism, fever, and lumbago. Zainon (2010: 8), on the other hand, states that jerangau cream is used externally for treating fever, skin disease, lumbago, sore eyes, and malaria. The plant is also consumed to heal coughing and sore throats. Besides the Malays, the Orang Asli (aboriginal people) of Malaysia have also used Acorus calamus to cure various 
ailments for generations (Katalog Pameran 2010: 8). From our random conversations with several elderly Bajau (the third largest ethnic group in Sabah), we found that the dried pulverised jerangau leaves were used to treat itchy skin. The Bajau would apply the dried jerangau powder made from the roots of Acorus calamus to their foreheads when they feel dizzy. The above testifies to the fact that for generations Acorus calamus has been one of the many popular medicinal plants among the various races and ethnic groups in Malaysia. Since the emphasis has been completely on the medicinal aspects of Acorus calamus, little is known about its religious and spiritual functions among the Malay, the Orang Asli, the Bajau of Malaysia or the Dusunic peoples of Malaysia.

4 Different Dusunic groups have their own terms for their ritual specialists. The Dusun and Kimaragang informants interviewed within this study called their ritual specialists bobolian, the Kadazan informants called them bobohizan, and the Rungus ones called them bobolizan. In terms of the practices of spiritual or traditional healing, the roles of a bobolian, bobohizan or bobolizan are similar to that of a shaman (see Kharitonova 2015). Like a shaman, a bobolian, bobohizan or bobolizan is believed to have the knowledge to communicate and negotiate with good and bad spirits in the nether world, especially during the spiritual healing ceremonies of the Dusunic people.

5 Beliefs in good and bad spirits and the harmonious relationship between them are traditionally common among the various cultures across the world. For example, Oak (2010: 97), who studied shamanism in early modern Korea, stated that according to the Korean traditional shamanistic worldview, diseases and disasters were caused by a breakdown in the cosmological harmony between spirits, human beings, and nature. A female mediator, a mudang, would perform kut ceremonies to repel disasters and call for blessings. Tatiana Panina (2011: 147), who studied the healing charms among the Udmurts, stated that the latter thought illnesses and unhealthy conditions were caused by supernatural beings - representatives of "the other world". The spirit of illness, considered to be one of these beings, breaks into this world, thereby shattering the order and stability of the objective reality. To re-establish the disturbed harmony, it is necessary to return the spirit to the beyond.

6 Based on the information gathered during our field trip in the District of Membakut Kecil on 18-19 July 2014, the Mamanta ritual was performed by the Kadazan ethnic people as an annual ritual to serve all sorts of spirits believed to be everywhere, in the rivers and seas, so that their homes would be safe and secure. When they were interviewed, several Kadazan informants in Membakut said that these rituals were effective in protecting what they had planted, for example, rice from being attacked by evil spirits and from being destroyed by natural disasters.

7 The fieldwork and direct observation was made in the house of Tialum binti Siwoi, a renowned and respected komboungo practitioner, on 18 July 2014. Tialum informed us that she had studied the different ways of using the komboungo in healing and spiritual rituals from a bobolian in Keningau. Also, Tialum's husband told us that people from faraway places had come to their house to consult with his wife about their personal problems and diseases.

8 Banknote of the lowest value of Malaysian Ringgit; RM3.50 $=\$ 1.00$ at the date of the interview. 


\section{REFERENCES}

Daily Express 2015 = Bobohizan Predicted Something Bad Will Happen. Daily Express, 6 June, p. 2.

Evans, Ivor H.N. 1953. The Religion of the Tempasuk Dusuns of North Borneo. Cambridge: Cambridge University Press.

Evans, Ivor H.N. 1978 [1922]. Among Primitive Peoples in Borneo. London: Seeley Service $\&$ Co. Ltd. Available at https://archive.org/details/amongprimitivepe00evanuoft, last accessed on 19 February 2018.

Hanafi Hussin 2003. Bobohizan dan Peranannya di Kalangan Masyarakat Kadazan Daerah Penampang, Sabah. [The Role of Bobohizan in the Kadazan Community of Penampang District.] JATI: Journal of Southeast Asian Studies, Vol. 8, No. 1, pp. $15-40$.

Hanafi Hussin 2007. Worldview dan Amalan: Pengalaman Kadazan Dataran Penampang. [Worldview and Practices: The Experience of the Kadazan in Penampang District.] Borneo Research Journal, Vol. 1, No. 1, pp. 7-29. Available at http:// umijms.um.edu.my/public/issue-view.php?id=367\&journal_id=40, last accessed on 19 February 2018.

Hanafi Hussin 2008. Performing Rice Farming Rituals by Penampang Kadazan of East Malaysia: Between Sacred Ritual and Secular Performance. JATI: Journal of Southeast Asian Studies, Vol. 13, pp. 173-190. Available at http://jati.um.edu. my/index.php/jati/issue/view/470, last accessed on 19 February 2018.

Hashmat Imam \& Zarnigar Riaz \& Mohd Azhar \& Ghulamuddin Sofi \& Azad Hussain 2013. Sweet Flag (Acorus calamus Linn.): An Incredible Medicinal Herb. International Journal of Green Pharmacy, Vol. 7, No. 4, pp. 288-296. http://dx.doi. org/10.22377/ijgp.v7i4.336.

Hurlbut, Hope M. 1986. Traditional Beliefs of the Eastern (Labuk) Kadazan People. Sabah Museum and Archives Journal, Vol. 1, No. 1, pp. 111-171.

Katalog Pameran $2010=$ Magis Pelantara Herba Orang Asli. [Orang Asli Herbs]. Exhibition Catalogue. Kuala Lumpur: Jabatan Muzium Malaysia.

Kharitonova, Valentina 2015. Revived Shamanism in the Social Life of Russia. Folklore: Electronic Journal of Folklore, Vol. 62, pp. 37-54. http://dx.doi.org/10.7592/ FEJF2015.62.kharitonova.

Koepping, Elizabeth 2006. Hunting with the Head: Borneo Villagers Negotiating Exclusivist Religion. Studies in World Christianity, Vol. 12, No. 1, pp. 59-78. http://dx.doi.org/10.3366/swc.2006.0003.

Lasimbang, Jannie 1996. The Indigenous Peoples of Sabah. In: Colin Nicholas \& Raajen Singh (eds.) Indigenous Peoples of Asia: Many Peoples, One Struggle. Bangkok: Asia Indigenous Peoples Pact, pp. 177-195.

Lasimbang, Rita 2002. Exploring the Art of the Bobohizan - Keeper of Kadazan Rituals and Chants. Borneo Research Council 7th Biennial International Conference, Universiti Malaysia Sabah, Kota Kinabalu, 15-18 July.

Low Kok On \& Marshall, Sanen. 2013. Paganism, Animism or Polytheism? An Investigation into the Labeling and Categorisation of Traditional Belief System of the Kadazandusun. The Sarawak Museum Journal, Vol. 71, No. 92, pp. 1-40. 
Low Kok On \& Pugh-Kitingan, Jacqueline 2015. Field Note: The Impact of Christianity on Traditional Agricultural Practices and Beliefs among the Kimaragang of Sabah: A Preliminary Study. Asian Ethnology, Vol. 74, No. 2, pp. 401-424.

Mat Zin Mat Kib 2003. Kristian di Sabah: 1881-1994. [Christians in Sabah: 1881-1994.] Bangi: Penerbit Universiti Kebangsaan Malaysia.

Morgan, George R. 1980. The Ethnobotany of Sweet Flag among North American Indians. Botanical Museum Leaflets, Vol. 28, No. 3, pp. 235-246. Available at https:// www.jstor.org/stable/41762831?seq=1\#page_scan_tab_contents, last accessed on 20 February 2018.

Motley, Timothy J. 1994. The Ethnobotany of Sweet Flag, Acorus Calamus (Araceae). Economic Botany, Vol. 48, No. 4, pp. 397-412. Available at https://www.jstor. org/stable/4255666?seq=1\#page_scan_tab_contents, last accessed on 20 February 2018.

Muhamad bin Zakaria \& Mustafa bin Ali Mohd 1994. Traditional Malay Medicinal Plants. Shah Alam: Penerbit Fajar Bakti Sdn. Bhd.

Oak, Sung-Deuk 2010. Healing and Exorcism: Christian Encounters with Shamanism in Early Modern Korea. Asian Ethnology, Vol. 69, No. 1, pp. 95-128. Available at http://asianethnology.org/downloads/ae/pdf/a1674.pdf, last accessed on 20 February 2018.

Panina, Tatiana 2011. Formulae for Expelling Illnesses/Diseases in Udmurt Charms and Prayers. Folklore: Electronic Journal of Folklore, Vol. 47, pp. 145-154. http:// dx.doi.org/10.7592/FEJF2011.47.panina.

Patrick, Tracy \& George Dol, Clarence 2015. Appeasing Mt. Kinabalu Spirits. Daily Express, 21 June, p. 1.

Phelan, Peter R. 2005. Comparisons: Sabah Local Customs and the Bible. Kota Kinabalu: Brother Peter R. Phelan.

Porodong, Paul 2001. Bobolizan, Forest and Gender Relations in Sabah, Malaysia. Gender, Technology and Development, Vol. 5, No. 1, pp. 63-90. http://dx.doi.org /10.1080/09718524.2001.11909986.

Pugh-Kitingan, Jacqueline \& Baptist, Judeth John 2009. Music for Cleansing the Universe - Drumming and Gong Ensemble Music in the Mamahui Pogun Ceremonies of the Lotud Dusun of Tuaran, Sabah, Malaysia. Borneo Research Bulletin, Vol. 40, pp. 249-276. Available at https://www.highbeam.com/doc/1G1-228122210.html, last accessed on 20 February 2018.

Ratsch, Christian 1998. The Encyclopedia of Psychoactive Plants: Ethnopharmacology and Its Applications. Rochester: Park Street Press.

Shimomoto, Yutaka 1979. Myths and Ritual for Rice Spirits Bambarazon among the Rungus. Asian Folklore Studies, Vol. 38, No. 2, pp. 73-93. DOI: 10.2307/1177685.

Tongkul, Felix 2002. Traditional Systems of Indigenous Peoples of Sabah, Malaysia: Wisdom Accumulated through Generations. Penampan: PACOS Trust.

Williams, Thomas Rhys 1965. The Dusun: A North Borneo Society. New York \& Chicago \& San Francisco \& London: Holt, Rinehart \& Winston.

Zainon Abu Samah \& Nurnida Mohd. Kamal \& Nuziah Hashim (eds.) 2010. Monograf Herba Malaysia, Jilid 2. [Monograph on Malaysian Herbs.] Kuala Lumpur: Institut Penyelidikan Perhutanan Malaysia. 